\title{
Sociobiology
}

RESEARCH ARTICLE - ANTS

\section{Lipid Mobilization and Acyl-Coenzyme A Dehydrogenase Abundance in the Postpharyngeal Gland of a Leaf-Cutting Ant}

\author{
AS VIEIRA, OC BUENO \\ Universidade Estadual Paulista (UNESP), Rio Claro-SP, Brazil
}

\author{
Article History \\ Edited by \\ Evandro Nascimento Silva, UEFS, Brazil \\ Received 14 March 2016 \\ Initial acceptance 08 June 2016 \\ Final acceptance 15 December 2016 \\ Publication date 13 January 2017

\section{Keywords} \\ Attini, confocal microscopy, hemolymph, \\ insects, GC-MS.

\section{Corresponding author} \\ Alexsandro Santana Vieira \\ Centro de Estudos de Insetos Sociais \\ Instituto de Biociências - UNESP \\ Av. 24A, no. 1515, Cx. Postal 199 \\ CEP: 13506-900, Rio Claro-SP, Brasil \\ E-Mail: alexsvieira@yahoo.com.br
}

\begin{abstract}
The postpharyngeal gland (PPG) in ants has a central role in lipid accumulation. Our objective was to investigate whether the PPG of workers of the leaf-cutting ant Atta sexdens rubropilosa (F.) performs lipid mobilization to the hemolymph, and to verify whether lipids in gland cells are in part oxidized to acetyl-CoA. Increased levels of fatty acids were observed in both the PPG and the hemolymph after $48 \mathrm{~h}$ of lipid supplementation. In contrast, after $120 \mathrm{~h}$ of lipid supplementation, fatty acid levels were reduced in the PPG and significantly increased in the hemolymph. The gland cells of the PPG of workers supplemented with lipids exhibited a high amount of AcylCoA dehydrogenase, and the lipids were in part $\beta$-oxidized to AcetylCoA. These findings suggest that the PPG of $A$. sexdens rubropilosa workers mobilize fatty acids from their gland cells to the hemolymph. Further work will be needed to elucidate lipid transport from the hemolymph to other organs in this organism.
\end{abstract}

\section{Introduction}

The Atta and Acromyrimex genera are popularly known as leaf-cutting ants, the most economically important ants. These ant species cut large amounts of fresh plant material to feed the symbiotic fungus Leucoagaricus gongylophorus Singer (M.), which in turn provides food for the larvae and in part for the adult (Hölldobler \& Wilson, 1990). The fatty acids may come either from feeding fungi or sap. Fungi are rich in carbohydrates and protein, and low in lipids (Martin et al., 1969). Sap may be ingested by workers while they are cutting and trimming leaves and, therefore, take lipids directly (Quinlan \& Cherrett, 1979). Therefore, studies have shown that the postpharyngeal glands (PPGs) are involved in lipid accumulation. PPG anatomy and lipid content were first described by Peregrine et al. (1972, 1973), Peregrine and Mudd (1974), Delage-Darchen (1976), and Vieira and Bueno (2015).
PPGs, the salivary system of ants, occur in pairs and are located dorsally in the transition between the pharynx and the esophagus regardless of sex, caste, or lifestyle (Hölldobler \& Wilson, 1990; Caetano, 1998). PPGs are of ectodermal origin and form during post-embryonic development (late prepupal stage) from two dorsal evaginations of the pharyngeal epithelium (Gama, 1985; Janet, 1905). Until recently, PPGs were thought to be exclusive to Formicidae (Delage-Darchen, 1976; Hölldobler \& Wilson, 1990), but Herzner et al. (2007) found them in the solitary wasps Philanthus triangulum (F.), Ampulex compressa (F.), Trachypus boharti (R.-E.), and Trachypus elongatus (F.) (Herzner et al., 2011; 2013).

PPGs also play a role in lipid metabolism (Peregrine et al., 1972, 1973; Peregrine \& Mudd 1974; Delage-Darchen, 1976; Decio et al., 2016). In insects, the fat body is the central organ for lipid metabolism, synthesizing several proteins and also acting as the storage site for carbohydrates, proteins, and 
mainly lipids (Arrese \& Soulages, 2010). However, the source of lipids in the PPG is controversial. One possibility is that lipids originate from secretions of the glandular epithelium itself. Another possibility is that it is taken up from the diet. Delage-Darchen (1976) proposed three hypotheses about the accumulation of lipid in PPGs: 1) transcellular route: lipids would penetrate the gland cells and be metabolized; 2) extraoral route: lipids would be regurgitated directly from the glands to other members of the colony; and 3) digestive route: lipids would flow from the glands to the crop and then to the midgut. Using labeled isotopes, Phillips and Vinson (1980) observed that, in Solenopsis invicta (B.), fatty acids and triacylglycerides injected into the hemolymph were not transferred to the PPGs, suggesting that lipids in this gland would be derived from food.

Delage-Darchen (1976) and Forbes and Macfarlane (1961) hypothesized that PPGs would be responsible for the digestion of ingested fats based on the presence of digestive enzymes such as lipases in the gland lumen (Peregrine et al., 1973; Vinson et al., 1980). The digestive route hypothesis proposed by Delage-Darchen (1976) was tested by Bueno (2005), which demonstrated that Atta sexdens rubropilosa workers were capable of separating, in the final portion of the pharynx, lipid from non-lipid compounds present in the ingested food. On a lipid-rich diet, these compounds would reach the PPGs and the non-lipid components (e.g., carbohydrates) would move to the crop, which would allow adults to use lipids available in nature (Bueno et al., 2008). Under extreme conditions, in which a large amount of lipid is offered to ants, some of it reaches the crop; however, sometime later, they return through the esophagus and enter the PPG (Phillips \& Vinson, 1980; Wheeler, 1994; Jesus, 2006; Bueno et al., 2008). Moreover, using autoradiography, liquid scintillation counting, and tritiated oleic acid, Bueno (2005) showed that lipids are mobilized into the lumen of glands of $A$. sexdens rubropilosa workers and queens, with subsequent absorption by the gland epithelium. However, little is known about the presence of fatty acids in the hemolymph. Therefore, the transcellular route hypothesis of Delage-Darchen (1976) should be tested: is the PPG of workers of the leaf-cutting ant $A$. sexdens rubropilosa capable of mobilizing lipids to the hemolymph?

In this way, the present study aimed to investigate whether the PPG of workers of the leaf-cutting ant $A$. sexdens rubropilosa performs lipid mobilization to the hemolymph. Workers of $A$. sexdens rubropilosa ants supplemented with lipids showed an increase in the amount of mitochondria and peroxisomes within PPG cells compared to those without supplement (Vieira \& Bueno, 2015) so, another aimed to verify whether lipids are in part oxidized to Acetyl-CoA in the mitochondria of gland cells.

\section{Material and Methods}

Part I - Gas chromatography/mass spectroscopy - lipid mobilization to the hemolymph
Bioassays I

Medium workers of $A$. sexdens rubropilosa were divided into three groups. Group BLS (before lipid supplement) received a pure diet and groups ALS (after lipid supplement) received pure diet with lipid supplementation for $48 \mathrm{~h}$ and 120 h. The pure diet consisted of $5 \%$ glucose, $1 \%$ casein peptone, $0.1 \%$ brewer's yeast extract, and $1.5 \%$ bacteriological agar. The diet of groups ALS consisted of $0.3 \mathrm{~mL}$ of soybean oil in $30 \mathrm{~mL}$ of pure diet. Each group contained 50 individuals that were placed in five Petri dishes (10 ants in each dish), and $0.5 \mathrm{~g}$ of supplementation was added daily to each dish for 25 days. The dishes were kept in a chamber incubator (BOD, Biochemistry Oxygen Demand) at $25 \pm 1{ }^{\circ} \mathrm{C}$ and at a relative humidity of $70 \%$. Five replicates were performed for each experimental group.

Chromatographic analysis was performed using medium workers of the group BLS, ALS $48 \mathrm{~h}$ and ALS $120 \mathrm{~h}$. A total of 114 workers were used for this analysis, or 57 ants for each extraction (hemolymph and PPG): 18 ants for group BLS, 18 for group ALS $48 \mathrm{~h}$, and 18 for group ALS $120 \mathrm{~h}$.

The hemolymph of the workers was extracted by capillarity. With a microcapillary tube, 0.5 to $0.75 \mu \mathrm{L}$ of hemolymph was extracted from the neck region of each ant and placed in vials. Each vial contained hemolymph from three ants, totaling six vials per group. After extraction, 0.5 $\mathrm{mL}$ of acetone was added to each vial.

PPGs from ants fed with and without lipid supplementation were extracted and three glands were placed in each vial, resulting in six vials per group; $0.5 \mathrm{~mL}$ of acetone was added to each vial and the PPGs were then macerated.

\section{Fischer Esterification (Methylation)}

Fischer esterification is a special type of esterification by refluxing a carboxylic acid and an alcohol in the presence of an acid catalyst (Fischer \& Speier, 1895). In our study, the hydrolysis of lipids through esterification was performed to obtain the corresponding fatty acid ester and thus facilitate its movement through the injector and chromatography column in the gas phase chromatography. Due to the esterification process, the fatty acids were identified in their ester form.

Samples underwent Fischer esterification prior to chromatographic analysis. The vials containing the hemolymph and the macerated PPGs were left half open to allow evaporation of acetone in an infrared weighing-machine at $60{ }^{\circ} \mathrm{C}$ (for approximately $20 \mathrm{~min}$ ). A saponification reaction was carried out by adding $0.3 \mathrm{~mL}$ of $0.5 \mathrm{~N} \mathrm{KOH}$ in anhydrous methanol, and the mixture was then homogenized and incubated at $60{ }^{\circ} \mathrm{C}$ for $20 \mathrm{~min}$. The esterification reaction was initiated by the addition of $0.5 \mathrm{~mL}$ of $0.9 \mathrm{~N} \mathrm{H}_{2} \mathrm{SO}_{4}$ in anhydrous methanol, and the mixture was homogenized and incubated at $60{ }^{\circ} \mathrm{C}$ for $20 \mathrm{~min}$. Next, $1 \mathrm{~mL}$ of hexane was added for spectrometry and the mixture homogenized. A biphasic solution was obtained, and $50 \mu \mathrm{L}$ were taken from 
the upper (aqueous) phase and placed in a new vial. The contents were then diluted with $450 \mu \mathrm{L}$ of hexane, and $1 \mu \mathrm{L}$ was injected into the gas chromatograph.

\section{Gas Phase Chromatography - Mass Spectrometry}

Chemical analyses were conducted at the Laboratory of Apicultural Products (Laboratório de Produtos Apícolas), Center for Studies of Social Insects (Centro de Estudos de Insetos Sociais - CEIS), using a gas chromatograph GC-210 (Shimadzu Scientific Instruments, Japan) equipped with an RTX MS capillary column $(30 \mathrm{~m} \times 0.25 \mathrm{~mm}$ ID, $0.25-\mu \mathrm{m}$ thick film) coupled to a mass-selective detector (Shimadzu GCMSQP2010 Plus). The gas chromatograph was connected to a computer and the data were processed using GCMSsolution software version 2.5. Elution was carried out with helium at 1 $\mathrm{mL} / \mathrm{min}$. Samples were injected using the splitless mode (port temperature: $250^{\circ} \mathrm{C}$ ) and held for $1 \mathrm{~min}$. The temperature of the column was set to start at $160{ }^{\circ} \mathrm{C}$ for $5 \mathrm{~min}$, increase to $200{ }^{\circ} \mathrm{C}$ at $5{ }^{\circ} \mathrm{C} / \mathrm{min}$, remain at $200^{\circ} \mathrm{C}$ for $3 \mathrm{~min}$, increase to $280^{\circ} \mathrm{C}$ at $8{ }^{\circ} \mathrm{C} / \mathrm{min}$, and remain at $280^{\circ} \mathrm{C}$ for $6 \mathrm{~min}$. The mass spectrometer was operated in the Electron Ionization mode at $70 \mathrm{eV}$, with a scanning range of 40 to $500 \mathrm{~m} / \mathrm{z}$. To allow sample identification and quantification, a calibration curve was obtained using fatty acid standards (lauric, myristic, palmitic, linoleic, oleic, stearic, and erucic acid) from SigmaAldrich at the following concentrations: $0.5,1,2,3$, and $5 \mathrm{ppm}$.

\section{Statistics}

After testing the data for normality, analysis of variance (ANOVA) was conducted with a significance level of $5 \%$ (0.05) between group BLS and groups ALS $48 \mathrm{~h}$ and ALS $120 \mathrm{~h}$. When significant differences were observed, a pairwise Tukey test was performed to check which groups were different from each other using Statistical software version 7.

\section{Part II - Confocal Microscopy - $\beta$-oxidation of fatty acids}

Bioassays II

Medium workers were divided into three groups of 24 individuals: two groups were fed a diet without lipid supplementation and starved for $48 \mathrm{~h}$ (FAST $48 \mathrm{~h}$ ) and $120 \mathrm{~h}$ (FAST $120 \mathrm{~h}$ ), whereas two groups were fed a diet supplemented with $2 \mu \mathrm{L}$ soybean oil placed in the mouthparts and starved for $48 \mathrm{~h}$ (LIPID $48 \mathrm{~h}$ ). Workers were placed individually in plastic containers $(200 \mathrm{~mL})$ and kept in a BOD incubator under controlled conditions $\left(25 \pm 1{ }^{\circ} \mathrm{C}\right.$; relative humidity of $\left.70 \%\right)$. Workers were anesthetized by cooling $\left(4{ }^{\circ} \mathrm{C}\right)$ for a few min, their heads were removed and placed in Petri dishes, and PPGs were dissected in insect saline solution $(0.128 \mathrm{M} \mathrm{NaCl}, 0.016 \mathrm{M}$ $\mathrm{Na}_{2} \mathrm{HPO}_{4}$, and 0.019 $\mathrm{MKH}_{2} \mathrm{PO}_{4}, \mathrm{pH} 7.2$ ) under a stereomicroscope using fine-tipped tweezers and surgical microscissors.

Confocal Laser Scanning Microscopy - immunofluorescence of the enzyme acyl-CoA dehydrogenase - $\beta$-oxidation of fatty acids
PPGs from groups FAST $48 \mathrm{~h}$, FAST $120 \mathrm{~h}$, and LIPID $48 \mathrm{~h}$ were used. After dissection, 24 glands were fixed in $4 \%$ paraformaldehyde for $30 \mathrm{~min}$ and then permeabilized with $0.1 \%$ Triton ${ }^{\circ} \mathrm{X}-100$ for $30 \mathrm{~min}$. The glands were incubated at $4{ }^{\circ} \mathrm{C}$ for $16 \mathrm{~h}$ with $10 \mu \mathrm{g} / \mathrm{mL}$ of anti-acyl-CoA dehydrogenase primary mouse monoclonal antibody (very long-chain acyl-CoA dehydrogenase, VLCAD, monoclonal antibody, Molecular Probes). Cy5-conjugated goat anti-mouse $\operatorname{IgG}(\mathrm{H}+\mathrm{L})$ (Molecular Probes) diluted 1:1,000 and incubated for $1 \mathrm{~h}$ was used as secondary antibody. At all stages, $10 \%$ goat serum was used as a blocking agent. Cell nuclei were counterstained with DAPI (4 ',6-diamino-2-fenilindol).

Immunofluorescence from VLCAD and nuclei (DAPI) in the PPGs were recorded in a confocal laser scanning microscope LSM780-NLO (Zeiss). Fluorescent images were obtained using lasers with $405 \mathrm{~nm}$ and $633 \mathrm{~nm}$ excitation wavelengths. Optical sections were acquired in a suitable Z-axis sectioning step $(0.63 \mu \mathrm{m}$ and $0.67 \mu \mathrm{m})$. Photography parameters were the same for all groups to quantify the emitted fluorescence intensity and to acquire images of the total gland area. ImageJ software and different modules of the Zeiss LSM780-NLO software were used for image analysis, including maximum projection (join all Z-axis sectioning step sizes). Fluorescence emission of PPG without incubation with primary antibody but only with Cy5 secondary antibody was used as negative control.

\section{Statistical Analysis}

Fluorescence emitted (grayscale) by immunofluorescence of the acyl-CoA dehydrogenase enzyme was quantified using ImageJ software. Using BioEstat statistical software, the Shapiro-Wilk test was carried out to assess normal distribution of data, and then the one-way ANOVA parametric statistical test was performed.

\section{Results}

Lipid mobilization to the hemolymph

Overall, four fatty acids (C16, C18:2, C18:1, and C18) were present in both the hemolymph and PPG of ants from groups BLS and ALS. Only two fatty acids, C16 and C18, were found in group BLS (Table 1, Fig 1A, 1B, and 1C).

Table 1. Fatty acid quantification in the hemolymph and postpharyngeal glands (PPG) of Atta sexdens rubropilosa workers before lipid supplementation (BLS).

\begin{tabular}{lllll}
\hline $\begin{array}{l}\text { Fatty acids } \\
\text { BLS }\end{array}$ & $\begin{array}{l}\text { Hemolymph } \\
(\mathrm{ppm})\end{array}$ & $\begin{array}{l}\text { Hemolymph } \\
(\%)\end{array}$ & $\begin{array}{l}\text { PPG } \\
(\mathrm{ppm})\end{array}$ & $\begin{array}{l}\text { PPG } \\
(\%)\end{array}$ \\
\hline Palmitic acid & 0.04716 & 53.43 & 0.06840 & 49.99 \\
Linoleic acid & 0 & 0 & 0 & 0 \\
Oleic acid & 0 & 0 & 0 & 0 \\
Stearic acid & 0.04110 & 46.57 & 0.06844 & 50.01 \\
Total & 0.08826 & 100 & 0.13685 & 100 \\
\hline
\end{tabular}


In addition to $\mathrm{C} 16$ and $\mathrm{C} 18$, two other fatty acids, $\mathrm{C} 18: 2$ and $\mathrm{C} 18: 1$, were found in the hemolymph and PPG in groups ALS $48 \mathrm{~h}$ and ALS $120 \mathrm{~h}$ (Tables 2 and 3; Fig 1B and 1C).
Fatty acid content in the hemolymph increased considerably in groups ALS $48 \mathrm{~h}$ and ALS $120 \mathrm{~h}$. Interestingly, fatty acid content increased in the PPG in the first $48 \mathrm{~h}$ of lipid
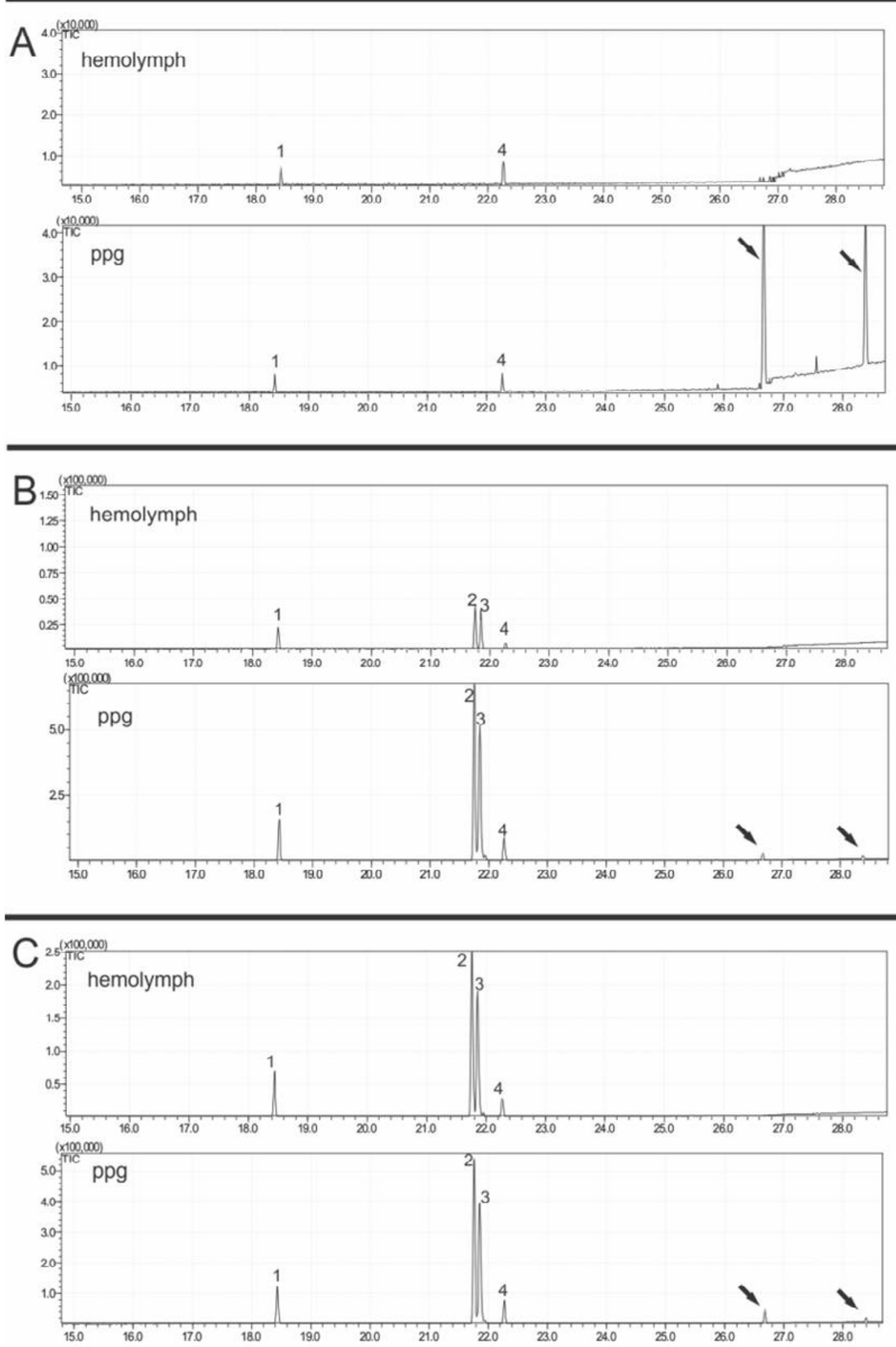

Fig 1. Chromatographic analysis of fatty acids in the hemolymph and postpharyngeal glands (PPG) of Atta sexdens rubropilosa workers. A. Group of workers before lipid supplementation (BLS). B. Group of workers after lipid supplementation for $48 \mathrm{~h}$ (ALS $48 \mathrm{~h}$ ). C. Group of workers after lipid supplementation for $120 \mathrm{~h}$ (ALS $120 \mathrm{~h}$ ). 1, palmitic acid; 2, stearic acid. Arrows indicate a saturated hydrocarbon (alkane) with different retention times. 
supplementation, but decreased after $120 \mathrm{~h}$ (Tables 1 to 3 ).

Palmitic Acid-C16. C16 was the predominant fatty acid in the hemolymph in group BLS (Table 1; Fig 1A), whereas in groups ALS $48 \mathrm{~h}$ and ALS $120 \mathrm{~h}$ it corresponded to the second and third most abundant fatty acid, respectively (Tables 2 and 3; Figs 1B and 1C). C16 was the second most abundant fatty acid in the PPG in group BLS (Table 1; Fig $1 \mathrm{~A})$, and the third most abundant in groups ALS $48 \mathrm{~h}$ and ALS $120 \mathrm{~h}$ (Tables 2 and 3; Fig 1B and 1C).

Linoleic Acid (C18:2). C18:2 was absent from the hemolymph in group BLS (Table 1; Fig 1A), whereas it was the predominant fatty acid in groups ALS $48 \mathrm{~h}$ and ALS 120 h (Tables 2 and 3; Fig 1B and C). C18:2 was also absent from the PPG in group BLS (Table 1; Fig 1A), but it was the predominant fatty acid in groups ALS $48 \mathrm{~h}$ and ALS $120 \mathrm{~h}$ (Tables 2 and 3; Fig 1B and 1C).

Oleic Acid (C18:1). C18:1 was absent from the hemolymph in group BLS (Table 1; Fig 1A). On the other hand, this fatty acid was the third and second most abundant in groups ALS $48 \mathrm{~h}$ and ALS $120 \mathrm{~h}$, respectively (Tables 2 and 3; Fig 1B and 1C). C18:1 was also absent from the PPG in group BLS (Table 1; Fig 1A), but it was the second most abundant fatty acid in groups ALS $48 \mathrm{~h}$ and ALS $120 \mathrm{~h}$ (Tables 2 and 3; Fig 1B and 1C).

Stearic Acid (C18). Ants of group BLS showed C18 as the second most abundant fatty acid in the hemolymph (Table 1; Fig 1A). C18 was the fourth most abundant fatty acid in groups ALS $48 \mathrm{~h}$ and ALS $120 \mathrm{~h}$ (Tables 2 and 3; Fig 1B and 1C). C18 was the predominant fatty acid in the PPG in group BLS (Table 1; Fig 1A), but it was only the fourth most abundant in groups ALS $48 \mathrm{~h}$ and ALS $120 \mathrm{~h}$ (Tables 2 and 3; Fig $1 \mathrm{~B}$ and $1 \mathrm{C})$.

Table 2. Fatty acid quantification in the hemolymph and postpharyngeal glands (PPG) of Atta sexdens rubropilosa workers after lipid supplementation for $48 \mathrm{~h}$ (ALS $48 \mathrm{~h}$ ).

\begin{tabular}{lllll}
\hline $\begin{array}{l}\text { Fatty acids } \\
\text { ALS 48 H }\end{array}$ & $\begin{array}{l}\text { Hemolymph } \\
(\mathrm{ppm})\end{array}$ & $\begin{array}{l}\text { Hemolymph } \\
(\%)\end{array}$ & $\begin{array}{l}\text { PPG } \\
(\mathrm{ppm})\end{array}$ & $\begin{array}{l}\text { PPG } \\
(\%)\end{array}$ \\
\hline Palmitic acid & 0.03918 & 21.22 & 0.50576 & 9.36 \\
Linoleic acid & 0.07802 & 42.25 & 3.03704 & 56.18 \\
Oleic acid & 0.03816 & 20.67 & 1.55904 & 28.84 \\
Stearic acid & 0.02929 & 15.86 & 0.30375 & 5.62 \\
Total & 0.18465 & 100 & 5.40559 & 100 \\
\hline
\end{tabular}

Hydrocarbons (HC). As can be seen in Figure 1A, two HCs identified as alkanes were detected in the PPG in group BLS. HCs were also observed in ants of groups ALS $48 \mathrm{~h}$ and ALS $120 \mathrm{~h}$, although with a smaller area than that in group BLS (Fig 1B and 1C).

One-way ANOVA revealed a statistically significant difference in fatty acid content in the hemolymph of groups ALS $48 \mathrm{~h}$ and ALS $120 \mathrm{~h}(\mathrm{~F}=6.9161, \mathrm{p}=0.0151)$ in comparison with group BLS (Fig 2). A posteriori Tukey test revealed a statistically significant difference between groups
Table 3. Fatty acid quantification in the hemolymph and postpharyngeal glands (PPG) of Atta sexdens rubropilosa workers after lipid supplementation for $120 \mathrm{~h}$ (ALS $120 \mathrm{~h}$ ).

\begin{tabular}{lllll}
\hline $\begin{array}{l}\text { Fatty acids } \\
\text { ALS 120 H }\end{array}$ & $\begin{array}{l}\text { Hemolymph } \\
(\mathrm{ppm})\end{array}$ & $\begin{array}{l}\text { Hemolymph } \\
(\%)\end{array}$ & $\begin{array}{l}\text { PPG } \\
(\mathrm{ppm})\end{array}$ & $\begin{array}{l}\text { PPG } \\
(\%)\end{array}$ \\
\hline Palmitic acid & 0.12077 & 19.94 & 0.45538 & 9.59 \\
Linoleic acid & 0.26897 & 44.41 & 2.65249 & 55.85 \\
Oleic acid & 0.14476 & 23.90 & 1.35750 & 28.58 \\
Stearic acid & 0.07113 & 11.75 & 0.28409 & 5.98 \\
Total & 0.60563 & 100 & 4.74946 & 100 \\
\hline
\end{tabular}

BLS and ALS $120 \mathrm{~h}(\mathrm{p}<0.05)$, as well as between groups ALS $48 \mathrm{~h}$ and ALS $120 \mathrm{~h}(\mathrm{p}<0.05)$. Although fatty acid content increased from group BLS to group ALS $48 \mathrm{~h}$, no statistically significant difference was found between these groups (Fig 2).

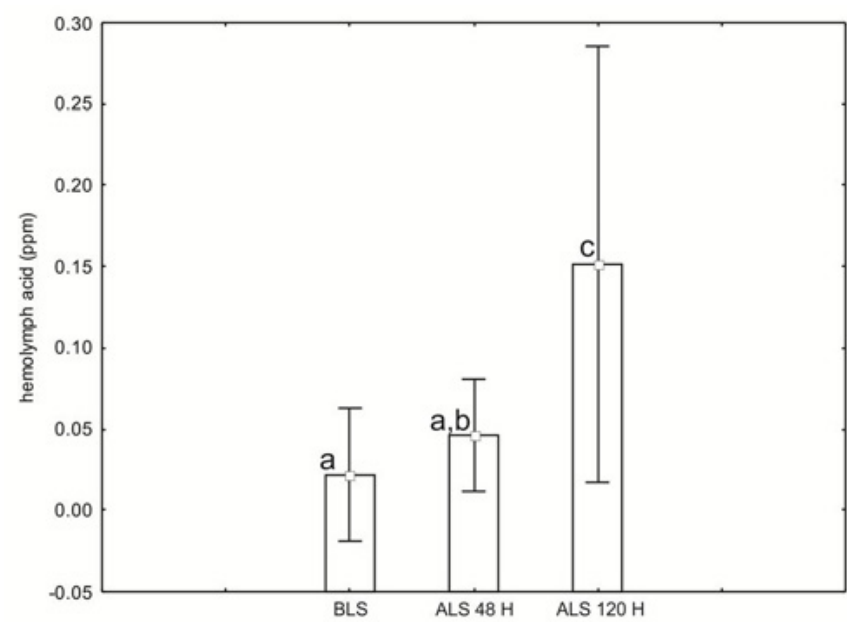

Fig 2. Mean concentration (ppm) and standard deviation of fatty acid content in the hemolymph in groups of workers before lipid supplementation (BLS) and after lipid supplementation (ALS $48 \mathrm{~h}$ and ALS $120 \mathrm{~h}$ ). Bars marked with the same letter show no statistically significant difference $(\mathrm{p}>0.05)$; bars marked with different letters show statistically significant differences $(\mathrm{p}<0.05)$. $\mathrm{P}$ values below $5 \%$ were considered significant.

A statistically significant difference in fatty acid content was found in PPGs of ants in group BLS compared to that in groups ALS $48 \mathrm{~h}$ and ALS $120 \mathrm{~h}$ ( $\mathrm{F}=13.6607$; $\mathrm{p}=0.0001)$. A posteriori Tukey test revealed a statistically significant difference between group BLS and groups ALS 48 $\mathrm{h}$ and ALS $120 \mathrm{~h}(\mathrm{p}<0.01)$, but not between group ALS $48 \mathrm{~h}$ and group ALS $120 \mathrm{~h}$ (Fig 3). The same pattern was found for individual fatty acids (Table 4). A schematic representation of lipid mobilization from the PPG to the hemolymph after lipid supplementation in leaf-cutting ants is shown in Fig 4.

\section{$\beta$-oxidation of fatty acids}

The PPGs of $A$. sexdens rubropilosa medium workers have two lobes (named left and right). These lobes have digitiform prolongations formed by a simple epithelium composed of epithelial cells with large, round nuclei (shown in Fig 5 in blue). Indirect immunofluorescence analysis of PPGs 


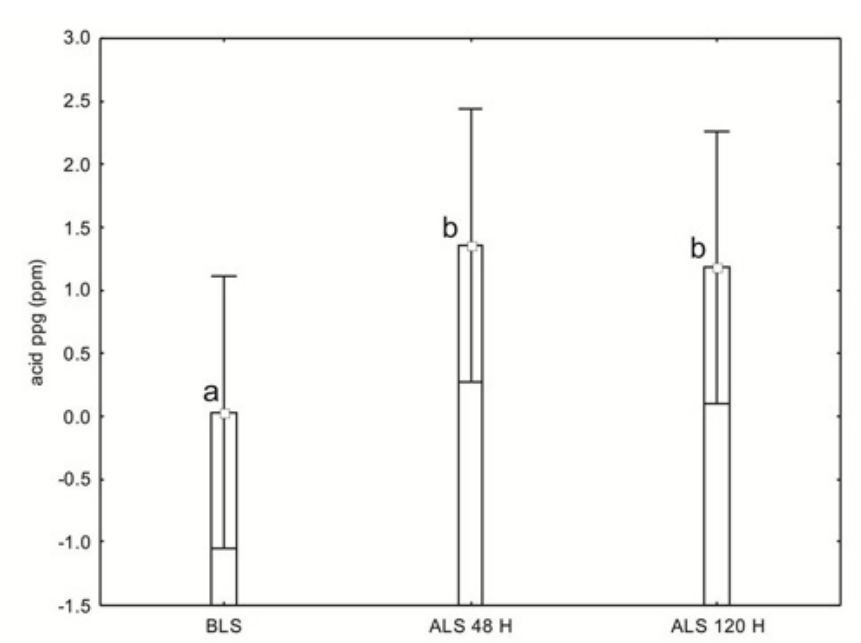

Fig 3. Mean concentration ( $\mathrm{ppm}$ ) and standard deviation of the fatty acid content in the postpharyngeal gland (PPG) in groups before lipid supplementation (BLS) and after lipid supplementation (ALS $48 \mathrm{~h}$ and ALS $120 \mathrm{~h}$ ). Bars marked with the same letter show no statistically significant difference $(\mathrm{p}>0.05)$; bars marked with different letters show statistically significant differences $(\mathrm{p}<0.01)$. P values below $5 \%$ were considered significant.

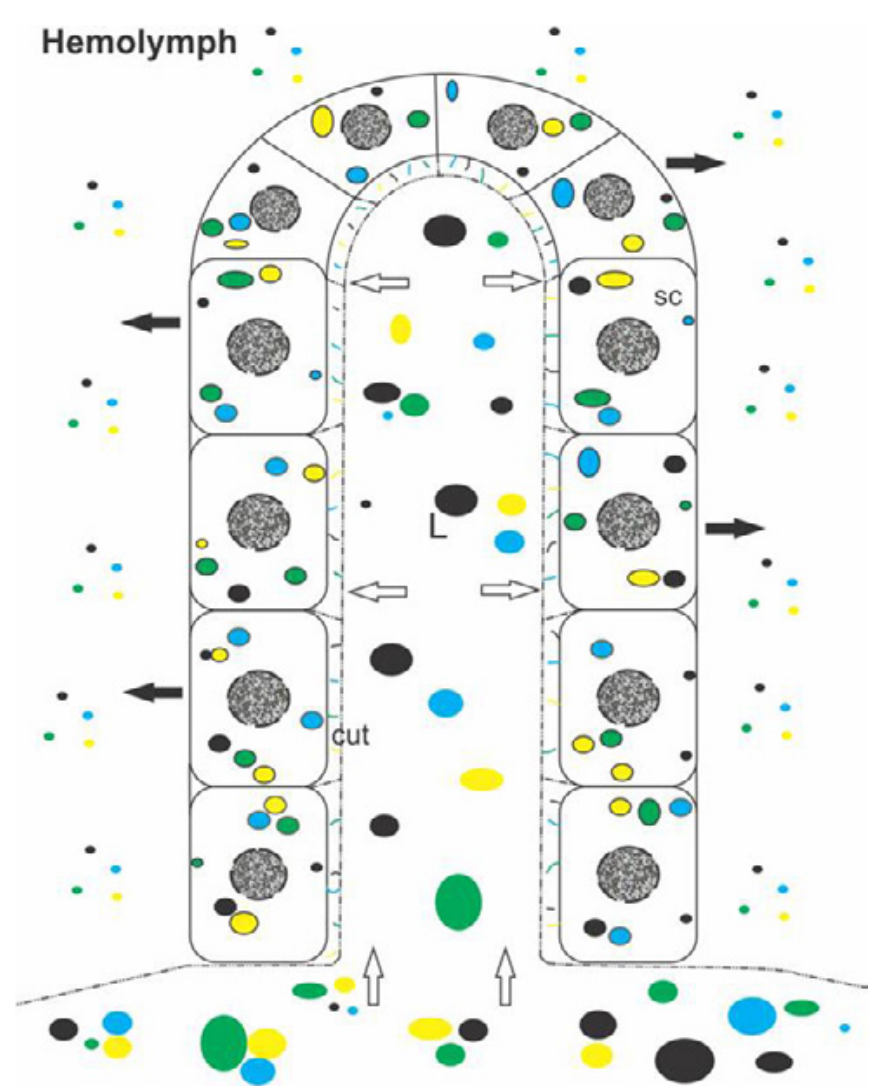

Fig 4. Schematic representation of lipid mobilization from the postpharyngeal gland (PPG) to the hemolymph after lipid supplementation in the leaf-cutting ant Atta sexdens rubropilosa. Lipids from the diet are forwarded (white arrow) to the lumen (L) of a digitiform prolongation in the PPG and arrive at the secretory cell (SC) after crossing the cuticle (cut). Once inside the cell, lipids are mobilized (black arrow) to the hemolymph. Fatty acids identified by GC-MS are shown as colored ovals: C16, green; C18, yellow; $\mathrm{C} 18: 1$, blue; C18:2, black. Oval size is proportional to the amount of fatty acid detected. of $A$. sexdens rubropilosa workers revealed a low fluorescence intensity, and therefore a low acyl-CoA dehydrogenase abundance, in cells of the digitiform prolongation in the PPGs in groups FAST $48 \mathrm{~h}$ and FAST $120 \mathrm{~h}$ (Fig 5A to 5D, red). In contrast, a strong fluorescence signal was detected in the PPGs of group LIPID $48 \mathrm{~h}$, indicating an abundance of acylCoA dehydrogenase in these cells (Fig 5E and 5F, red).

After quantification of the emitted fluorescence intensity, statistical analysis was performed. A statistically significant difference was found between groups with (LIPID $48 \mathrm{~h}$ ) and without (FAST $48 \mathrm{~h}$ and FAST $120 \mathrm{~h}$ ) lipid supplementation $(\mathrm{F}=7.978 ; \mathrm{p}=0.0065)$. A posteriori pairwise Tukey test revealed a significant difference between groups FAST $48 \mathrm{~h}$ and LIPID $48 \mathrm{~h}(\mathrm{p}<0.05)$, as well as between groups FAST $120 \mathrm{~h}$ and LIPID $48 \mathrm{~h}(\mathrm{p}<0.01)$ (Fig 6). P values below $5 \%$ were considered significant.

Table 4. One-way ANOVA of fatty acid content in the postpharyngeal gland (PPG) of $A$. sexdens rubropilosa workers between groups before lipid supplementation (BLS) and after lipid supplementation (ALS) for 48 and $120 \mathrm{~h}$. P values below $5 \%$ were considered significant.

\begin{tabular}{|c|c|c|c|c|}
\hline \multirow{2}{*}{$\begin{array}{l}\text { Fatty acids } \\
\text { - PPG }\end{array}$} & \multirow[b]{2}{*}{ ANOVA } & \multicolumn{3}{|l|}{ Tukey } \\
\hline & & $\begin{array}{l}\text { BLS and } \\
\text { ALS } 48 \mathrm{~h}\end{array}$ & $\begin{array}{l}\text { BLS and } \\
\text { ALS } 120 \mathrm{~h}\end{array}$ & $\begin{array}{l}\text { ALS } 48 \mathrm{~h} \text { and } \\
\text { ALS } 120 \mathrm{~h}\end{array}$ \\
\hline $\begin{array}{l}\text { Palmitic } \\
\text { acid }\end{array}$ & $\begin{array}{l}F(2.15)=26.952, \\
p<0.01\end{array}$ & $\mathrm{p}<0.01$ & $\mathrm{p}<0.01$ & $\mathrm{p}>0.05$ \\
\hline $\begin{array}{l}\text { Linoleic } \\
\text { acid }\end{array}$ & $\begin{array}{l}\mathrm{F}(2.15)=24.426, \\
\mathrm{p}<0.01\end{array}$ & $\mathrm{p}<0.01$ & $\mathrm{p}<0.01$ & $\mathrm{p}>0.05$ \\
\hline Oleic acid & $\begin{array}{l}F(2.15)=33.718 \\
p<0.01\end{array}$ & $\mathrm{p}<0.01$ & $\mathrm{p}<0.01$ & $\mathrm{p}>0.05$ \\
\hline $\begin{array}{l}\text { Stearic } \\
\text { acid }\end{array}$ & $\begin{array}{l}F(2.15)=32.302 \\
p<0.01\end{array}$ & $\mathrm{p}<0.01$ & $\mathrm{p}<0.01$ & $\mathrm{p}>0.05$ \\
\hline
\end{tabular}

$\mathrm{P}$ values below $5 \%$ were considered significant.

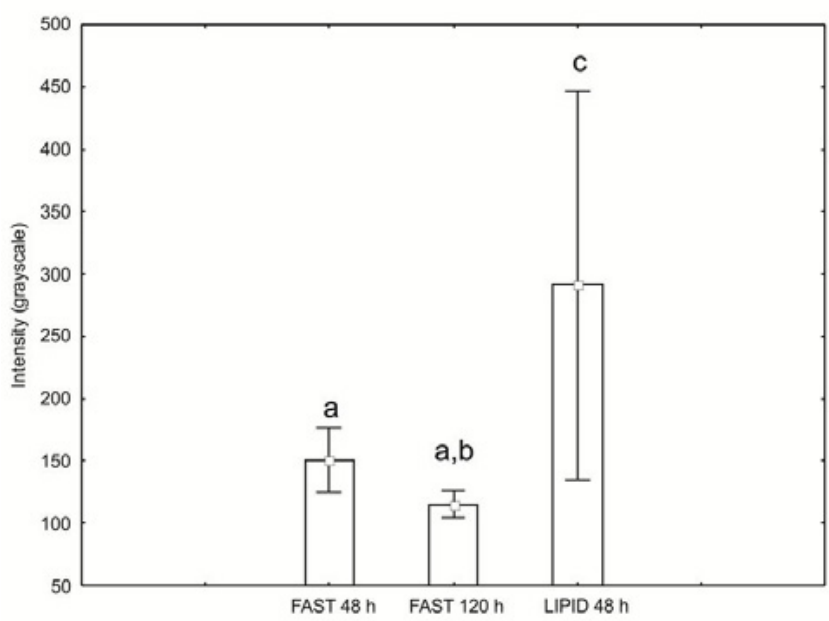

Fig 6. One-way ANOVA analysis of fluorescence intensity (values in grey scale) reflecting acyl-CoA dehydrogenase abundance in the measured areas of a gland cell of postpharyngeal glands of Atta sexdens rubropilosa workers in groups without (FAST 48 and FAST $120 \mathrm{~h}$ ) and with (LIPID $48 \mathrm{~h}$ ) lipid supplementation. Bars marked with the same letter show no statistically significant difference $(\mathrm{p}>$ 0.05 ); bars marked with different letters show statistically significant differences $(\mathrm{p}<0.05)$. P values below $5 \%$ were considered significant. 

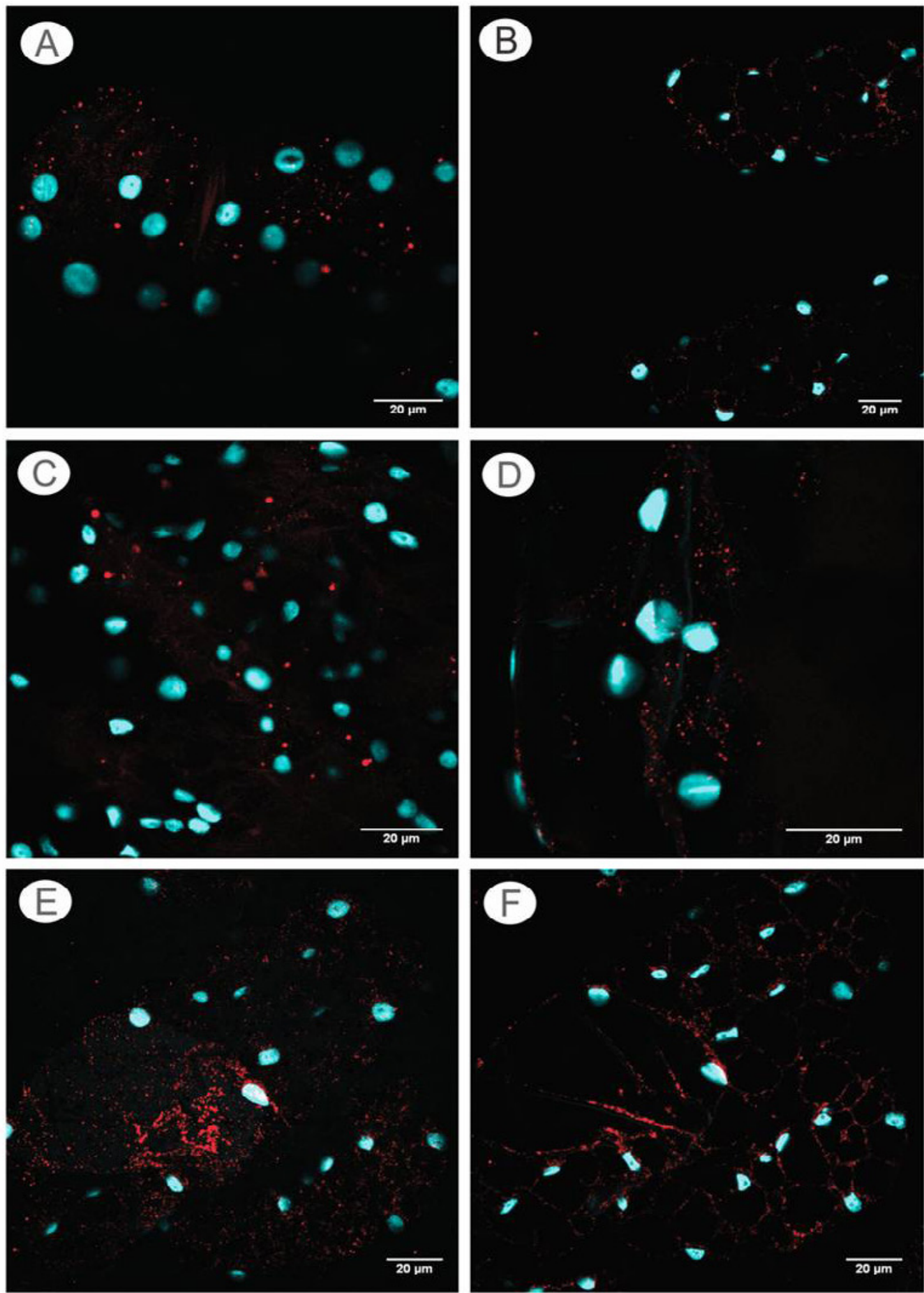

Fig 5. Confocal microscopy analysis of postpharyngeal glands (PPG) of Atta sexdens rubropilosa workers showing the fluorescence emitted (Cy5) by immunofluorescence of Acyl-CoA dehydrogenase (red) and stained (DAPI) nuclei (blue). A-B. Digitiform prolongation of the PPG of a worker from group FAST $48 \mathrm{~h}$ showing nuclei and the low abundance of Acyl-CoA dehydrogenase in gland cells. C-D. Digitiform prolongation of the PPG of a worker from group FAST $120 \mathrm{~h}$ showing nuclei and the low abundance of AcylCoA dehydrogenase in gland cells. E-F. Digitiform prolongation of the PPG of a worker from group LIPID $48 \mathrm{~h}$ showing nuclei and the high abundance of Acyl-CoA dehydrogenase in gland cells.

\section{Discussion}

The presence of lipid inside PPGs has been observed in several ant species, and its origin is controversial. One possibility is that lipid would originate from secretions of the glandular epithelium itself; others believe it comes from food.
Our study has shown that $A$. sexdens rubropilosa workers from group BLS contained two fatty acids (C16 and C18) both in the PPG and hemolymph. Fatty acids may come either from feeding the fungi or from sap. Fungi are rich in carbohydrates and protein, but poor in lipids (Martin et al., 1969). Workers may ingest sap during cutting and trimming 
leaves, and, therefore, lipids may be taken directly (Quinlan \& Cherrett, 1979). The two fatty acids (C16 and C18) we have detected in the PPG may thus be obtained either from fungal food or from cutting leaves.

In previous studies using cytochemical ultrastructural analysis, Vieira and Bueno (2015) observed lipid droplets in the basal plasma membrane near the hemolymph. Our study demonstrated that when ants were supplemented with lipids (groups ALS $48 \mathrm{~h}$ and ALS $120 \mathrm{~h}$ ), two additional fatty acids (18:2 and C18:1) were found both in the PPG and hemolymph. These results are in agreement with the transcellular route hypothesis of Delage-Darchen (1976), in which lipids go from the lumen to the gland cells and are then metabolized. Phillips and Vinson (1980) observed in S. invicta that fatty acids and triacylglycerides injected into the hemolymph did not reach the interior of the PPGs. According to Arrese and Soulages (2010), in insects, lipids from food reach the digestive tract and are then transported by lipoproteins to the fat body for storage. After metabolization of these lipids according to nutritional needs, they are transported to the hemolymph and from there distributed to the tissues. We suggest that lipids reach the hemolymph from the PPG after lipid supplementation. The PPG would therefore be capable of storing lipids and of secreting them into the hemolymph, from which these molecules can be stored in the fat body.

The entry of lipids into the PPGs and subsequent mobilization to the hemolymph requires some type of hydrolysis. The hydrolysis of triacylglycerol to free fatty acids may initially involve lipases (Alberts et al., 2010). Lipases have not been found in the PPGs of Acromyrmex octospinosus (F.) (Febvay \& Kermarrec, 1986), and $\alpha$-glucosidase and esterase were detected at low levels in the PPG. The authors suggested that this gland does not have a digestive function, as hypothesized by Delage-Darchen (1976). It has been shown that lipids from the diet go straight to the PPG and that, when large amounts of lipids are offered to ants, some of it reaches the crop, but not the midgut (Bueno et al., 2008). Erthal et al. (2004) detected $\alpha$-glucosidase as the most abundant enzyme in the midgut of leaf-cutting ants, indicating that it is probably involved in glucose assimilation from nutrient sources such as maltose and sucrose present in plant material. Decio et al. (2016) showed that the PPG is an organ specialized for lipid nutrition in leaf-cutting ants, and this organ is responsible for lipid metabolism in A. sexdens rubropilosa. Furthermore, two proteins responsible for lipid transport in PPG cells, long-chain fatty acid transport protein and fatty acid binding protein, were shown to be present in higher amounts in ants fed with lipid supplementation than in ants fed without lipid supplementation (Decio et al., 2016). These proteins act as carriers and direct the mobilization of lipids into or out of the cell (Börchers \& Spener, 1994; Schaffera \& Lodish, 1994). Based on our results, we believe that the PPG of leaf-cutting ants is also specialized in lipid mobilization to the hemolymph.

Statistical analysis showed that lipid supplementation caused fatty acid accumulation in the PPG during the first $48 \mathrm{~h}$, with moderate mobilization of individual fatty acids to the hemolymph. However, after 120 hours of lipid supplementation, mobilization of fatty acids to the hemolymph was greatly increased, with a concomitant decrease in fatty acid content in the PPG. These results are in agreement with those described by Bueno (2005), in which $A$. sexdens rubropilosa workers fed on tritiated oleic acid showed a decrease in lipid content in the PPG after $120 \mathrm{~h}$. Therefore, our results indicate that lipid mobilization from the PPG to the hemolymph occurs after some time, and that this delay reflects the storage capacity of its gland cells.

Since the abundance of different fatty acids in the PPG and the hemolymph vary between groups BLS and ALS, we believe that lipid mobilization from the PPG to the hemolymph may depend on both the nutritional needs and the resources available to $A$. sexdens rubropilosa workers. Furthermore, C18:1 and C18:2 in group ALS may be used as vehicles for active ingredients in the chemical control of leaf-cutting ants. Corroborating this idea, we detected C18:2 as the most abundant fatty acid in both the hemolymph and PPG in groups ALS 48 and ALS $120 \mathrm{~h}$, whereas C18:1 was the second most abundant. Thus, after lipid supplementation, C18:2 becomes the main fatty acid in the PPG and hemolymph of $A$. sexdens rubropilosa workers. Toxicological bioassays conducted with hydramethylnon diluted in soybean oil and $A$. sexdens rubropilosa (Sumida, 2007; Decio et al., 2013) showed a possible alternative route of ingestion of this active ingredient in the PPGs of leaf-cutting ants with increased pesticide action.

The presence of hydrocarbons (alkanes) in the PPGs of groups BLS, ALS $48 \mathrm{~h}$, and ALS $120 \mathrm{~h}$ may result from allogrooming or from the cuticle. Soroker et al. (1998) and Morgan (2008) showed that hydrocarbon mobilization to the PPG could occur by allogrooming. A study on hydrocarbon biosynthesis in Cataglyphis niger (A.) showed that some lipids, but not hydrocarbons, are synthesized in the gland (Soroker \& Hefetz, 2000). Still, Bagnères and Morgan (1991) demonstrated that, in several ant species, the PPGs contain the same substances that are found in the cuticle, i.e., mainly long-chain acids and esters. It is possible that the presence of hydrocarbons in the PPG of $A$. sexdens rubropilosa reflects the fact that this organ is of ectodermal origin, i.e., it has a cuticle, and that these alkanes originate from the cuticle.

The most abundant organelles in PPGs are mitochondria, distributed throughout the cytoplasm. In the PPG of Camponotus rufipes (F.), Dinoponera australis (E.), and Dinoponera quadriceps (K.), mitochondria are elongated and show different sizes (Falco, 1992; Schoeters \& Billen, 1997). Recent studies by Vieira and Bueno (2015) have found an increase in the number of peroxisomes and mitochondria in gland cells of the PPG of A. sexdens rubropilosa workers when subjected to lipid supplementation. The mitochondrial organelle is responsible for the $\beta$-oxidation of fatty acids to Acetyl-CoA, which then enters the citric acid cycle to be further oxidized and generate ATP (Alberts et al., 2010; 
Nelson \& Cox, 2014). Decio et al. (2016) showed that part of the lipids in the PPG of mated females are used as substrate for the synthesis of Acetyl-CoA. Based on these findings, we investigated the $\beta$-oxidation of fatty acids in the PPG of workers and the results were surprising: they show a low abundance of Acyl-CoA dehydrogenase in PPG cells of workers in groups FAST $48 \mathrm{~h}$ and FAST $120 \mathrm{~h}$, and a high abundance in group LIPID $48 \mathrm{~h}$. PPGs of both the mated females (Decio et al., 2016) and the A. sexdens rubropilosa workers in our study metabolized part of the lipids by $\beta$-oxidation. We hypothesize that the energy produced in gland cells by $\beta$-oxidation is necessary for lipid mobilization between the PPG and the hemolymph.

Finally, we conclude that the PPG of A. sexdens rubropilosa workers mobilize fatty acids from their gland cells to the hemolymph. Therefore, in addition to performing lipid metabolism (Decio et al., 2016), the PPG is also an organ specialized in lipid mobilization to the hemolymph. Further work will be needed to elucidate lipid transport from the hemolymph to other organs in this organism.

\section{Acknowledgements}

We thank technician Sebastião Zanão from the Gas Chromatography - Mass Spectrometry Laboratory (UNESP) for his help with the protocol and handling of the equipment and technician Mariana Ozello Baratti from the Confocal Microscopy Laboratory INFABIC-UNICAMP, Campinas, SP, Brazil. We also thank the São Paulo Research Foundation (FAPESP) (Grant 2012/12541-3) and the National Council for Scientific and Technological Development (CNPq) (Grant 157837/2015-7) for financial support.

\section{References}

Alberts, B., Johnson, A. \& Walter, P. (2010). Biologia Molecular da Célula, vol. 1054 (5). Artmed, Porto Alegre.

Arrese, E.L. \& Soulages, J.L. (2010). Insect fat body: energy, metabolism, and regulation. Annual Review of Entomology, 55: 207-225. doi: 10.1146/annurev-ento-112408-085356

Bagnères, A.-G. \& Morgan, E.D. (1991). The postpharyngeal gland and the cuticle of Formicidae contain the same characteristic hydrocarbons. Experientia (Basel), 47: 106-111.

Börchers, T., Spener, F. (1994). Fatty acid binding proteins. In: Hoekstra D. editor. Cell Lipids. London: Academic Press.

Bueno, O.C., Morini, M.S.C., Pagnocca, F.C., Hebling, M.J.A. \& Silva, O.A. (1997). Sobrevivência de operárias de Atta sexdens rubropilosa Forel (Hymenoptera: Formicidae) isoladas do formigueiro e alimentadas com dietas artificiais Anais da Sociedade Entomológica do Brasil, 26: 107-112.

Bueno, O.C. (2005). Filtro infrabucal e glândulas pós-faríngeas da saúva-limão Atta sexdens rubropilosa Forel (Hymenoptera,
Formicidae). 107f. Tese (Livre-Docência) - Instituto de Biociências, Universidade Estadual Paulista "Júlio de Mesquita Filho", Rio Claro.

Bueno, O.C., Bueno, F.C., Diniz, E.A. \& Schneidar, M.O. (2008). Utilização de alimento pelas formigas-cortadeiras. In: Vilela, E. F. (ed) et al. Insetos Sociais: da biologia a aplicação. Viçosa: UFV, p. 96-114.

Caetano, F.H. (1998). Aspectos ultramorfológicos, ultraestruturais e enzimológicos da glândula pós-faríngea de Dinoponera australis (Formicidae: Ponerinae). 137f. Tese (Livre-Docência), Instituto de Biociências, Universidade Estadual Paulista "Júlio de Mesquita Filho", Rio Claro.

Decio, P., Silva-Zacarin, E.C.M., Bueno, F. \& Bueno, O.C. (2013). Toxicological and histopathological effects of hydramethylnon on Atta sexdens rubropilosa (Hymenoptera: Formicidae) workers. Micron, 45: 22-31. doi: 10.1016/j. micron.2012.10.008

Decio P., Vieira, A.S., Dias, N.B., Palma, M.S., Bueno, O.C. (2016). The Postpharyngeal Gland: Specialized Organ for Lipid Nutrition in Leaf-Cutting Ants. PLOS ONE 11(5): e0154891. doi:10.1371/ journal.pone.0154891

Delage-Darchen, B. (1976). Les glandes postpharyngeal dês fourmis connaissances actuellessur leur structure, leur fonctionnement, leur rôle. L'Année Biologique, 15(1-2): 63-76.

Erthal, M.Jr., Silva, C.P. \& Samuels, R.I. (2004). Digestive enzymes of leaf-cutting ants, Acromyrmex subterraneus (Hymenoptera: Formicidae: Attini): distribution in the gut of adult workers and partial characterization. Journal of Insect Physiology, 50: 881-891. doi: 10.1016/j.jinsphys.2004.06.009

Falco, J.R. (1992). Comparação ultraestrutural entre glândulas pós-faríngeas de Camponotus rufipes (Hymenoptera: Formicidae) parasitadas e não por nematoides, $70 \mathrm{f}$. Trabalho de Conclusão de Curso (Ciências Biológicas) - Instituto de Biociências, Universidade Estadual Paulista "Júlio de Mesquita Filho", Rio Claro.

Febvay, G. \& Kermarrec, A, (1986). Digestive Physiology of leaf-cutting ants. In: Lof-gren, C.S., Vander Meer, R.K. (Eds.), Fire ants and leaf-cutting ants: Biology andmanagement. Westview Press, Boulder, pp. 274-285.

Fischer, E. \& Speier, A. (1895). "Darstellung der Ester". Chem. Ber., 28: 3252-3258.

Forbes, J. \& Mcfarlane, A.M. (1961). The comparative anatomy of digestive glands in the female castes and the male of Camponotus pennsylvanicus Degeer (Formicidae, Hymenoptera). Journal of the New York Entomological Society, 69: 92-103.

Gama, V. (1985). O sistema salivar de Camponotus (Myrmothrix) rufipes (Fabricius, 1775), (Hymenoptera: Formicidae). Revista Brasileira de Biologia, 45: 317-359. 
Herzner, G., Goettler, W., Kroiss, J., Purea, A., Webb, A.G., Jakob, P.M., Rössler, W. \& Strohm, E. (2007). Males of a solitary wasp possess a postpharyngeal gland. Arthropod Structure \& Development, 36: 123-133.

Herzner, G., Ruther, J., Goller, S., Schulz, S., Goettler, W. \& Strohm, E. (2011). Structure, chemical composition and putative function of the postpharyngeal gland of the emerald cockroach wasp, Ampulex compressa (Hymenoptera, Ampulicidae). Zoology [S.I.], 114: 36-45. doi: 10.1016/j. zool.2010.10.002.

Herzner, G., Kaltenpoth, M., Poettinger, T., Weiss, K., Koedam, D., Kroiss, J. \& Strohm, E. (2013). Morphology, Chemistry and Function of the Postpharyngeal Gland in the South American Digger Wasps Trachypus boharti and Trachypus elongates. PLOS ONE, 8(12): e82780. doi: 10.1371/ journal.pone.0082780

Hölldobler, B. \& Wilson, E.O. (1990). The ants. London: Springer, 732p.

Janet, C. (1905) Anatomie de la tête du Lasius niger. Paris: Limoges Impremeire-libraire. Ducourtieux et Gout, 40p.

Jesus, C.M. (2006). Utilização de alimentos contendo substâncias lipídicas e açucaradas por formigas urbanas. $99 \mathrm{f}$. Dissertação (Mestrado) - Instituto de Biociências, Universidade Estadual Paulista “Júlio de Mesquita Filho", Rio Claro, SP.

Nelson, D.L. \& Cox, M.M. (2014). Princípios de bioquímica de Lehninger. Porto Alegre: Artmed, 6. ed. Porto Alegre: Artmed.

Martin, M.M., Carman, R.M. \& MacConnel, J.G. (1969). Nutrients derived from the fungus cultured by the attini ant Atta colombica tonsipes. Annals of the Entomological Society of America, 62: 1386-1387.

Morgan, E.D. (2008). Chemical sorcery for sociality: Exocrine secretions of ants (Hymenoptera: Formicidae). Myrmecol News, 11: 79-90.

Peregrine, D.J., Mudd, A. \& Cherret, J.M. (1973). Anatomy and preliminary chemical analysis of postpharyngeal glands of leaf-cutting ant, Acromyrmex octospinosus (Reich.) (Hym., Formicidae). Insectes Sociaux, 20(4): 355-363

Peregrine, D.J. \& Mudd, A. (1974). The effects of diet on the composition of the postpharyngeal glands of Acromyrmex octospinosus (Reich). Insectes Sociaux, 21: 417-424.

Peregrine, D.J., Percy, H.C. \& Cherrett, J.M. (1972). Intake and possible transfer of lipid by the postpharyngeal glands of Atta cephalotes L. Entomologia Experimentalis Et Applicata, 15: 248-258.
Phillips, S.A. (1979). Physiology of the postpharyngeal glands and comparative morphology of glands associatedwith the mouthparts among castes of the red imported fire ant, Solenopsis invicta Buren. 67 f. Dissertação (Mestrado) Texas A \& M University

Phillips, -Jr.S.A. \& Vinson, S.B. (1980). Source of the postpharyngeal gland contents in the red imported fire ant, Solenopsis invicta. Annals of the Entomological Society of America, 73: 257-261.

Quinlan, R.J. \& Cherrett, J.M. (1979). The role of fungus in the diet of the leaf-cutting ant Atta cephalotes (L.). Ecological Entomology, 4: 151-160.

Schaffera, J.E., Lodish, H.F. (1994). Expression cloning and characterization of a novel adipocyte long chain fatty acid transport protein. Cell, 79: 427-436. PMID: 7954810.

Schoeters, E. \& Billen, J. (1997). The postpharyngeal gland in Dinoponera ants (Hymenoptera: Formicidae): unusual morphology and changes during the secretory process. International Journal of Insect Morphology and Embryology, 25: 443-447. doi: 10.1016/S0020-7322(96)00016-5

Soroker, V., Fresneau, D. \& Hefetz, A. (1998). Formation of colony odor in ponerine ant Pachychondyla apicalis. Journal of Chemical Ecology, 24: 1077-1090.

Soroker, V. \& Hefetz, A. (2000). Hydrocarbon site of synthesis and circulation in the desert ant Cataglyphis niger. Journal of Insect Physiology, 46: 1097-1102. doi: 10.1016/ S0022-1910(99)00219-X

Sumida, S.S. (2007). Trabalho de Conclusão de Curso (Graduação em Ciências Biológicas), Análise Morfológica dos túbulos de Malpighi, do ventrículo e das glândulas pósfaríngeas das operárias adultas de Atta sexdens rubropilosa, Forel,1908, tratadas com compostos químicos. 53f. Instituto de Biociências, UNESP, Rio Claro, São Paulo.

Vieira, A.S. \& Bueno, O.C. (2015). Mitochondrial and peroxisomal population in postpharyngeal glandsof leafcutting ants after lipid supplementation. Micron, 68: 8-16. doi:10.1016/j.micron.2014.08.004

Vinson, S.B., Phillips, S.A. \& Willians, H.J. (1980). The function of the postpharyngeal glands of the red imported fire ant, Solenopsis invicta, Buren. Journal of Insect Physiology, 20: 645-650.

Wheeler, D.E. (1994). Nourishment in ants: patterns in individuals and societies. In: Hunt, J. H.; Nalepa, C. A. (Ed.). Nourishment \& evolution in insect societies. Boulder, Colorado: Westview Press. p. 245-278. 